\title{
Polychaete species diversity on the West Antarctic Peninsula deep continental shelf
}

\author{
L. Neal ${ }^{1}$, S. L. Mincks Hardy ${ }^{2}$, C. R. Smith ${ }^{3}$, A. G. Glover ${ }^{1, *}$ \\ ${ }^{1}$ Zoology Department, The Natural History Museum, Cromwell Road, London SW7 5BD, UK \\ ${ }^{2}$ School of Fisheries and Ocean Sciences, University of Alaska, PO Box 757220, Fairbanks, Alaska 99775, USA \\ ${ }^{3}$ Department of Oceanography, University of Hawaii, 1000 Pope Road, Honolulu, Hawaii 96822, USA
}

\begin{abstract}
We assessed macrofaunal polychaete species diversity on the West Antarctic Peninsula at mean depths of 500 to $600 \mathrm{~m}$ along a cross-shelf transect near Anvers Island, Antarctica. Fifteen megacore samples from 3 sites were analysed to species level, revealing 78 polychaete species of which several are new to science. Quantitative samples allowed an assessment of species abundances and the relative contribution of dominance to overall species diversity. The composition of the assemblages varied across the shelf: the 2 outermost stations on the transect were relatively similar but differed from the innermost station, which had higher diversity and major differences in species composition, possibly linked to changes in the sediment characteristics and degree of food availability. Species diversity, measured by rarefaction, evenness and species richness estimators, was similar to values reported at other bathyal settings and slightly higher than that reported from the Arctic shelf, but in general lower than that reported at temperate and tropical abyssal sites. Dominance was much higher at Antarctic deep-shelf sites in comparison to temperate bathyal and abyssal sites.
\end{abstract}

KEY WORDS: Marine benthos $\cdot$ Southern Ocean $\cdot$ Biodiversity $\cdot$ Polychaeta $\cdot$ Annelida $\cdot$ Aurospio Resale or republication not permitted without written consent of the publisher

\section{INTRODUCTION}

Species diversity, encompassing both species richness and dominance, is not constant across habitats, communities or ecosystems. Variance in species diversity and its causes have been of primary interest to ecologists since the discipline was first invented. Locally operating variables such as productivity, disturbance, recruitment, predation, competitive exclusion and environmental heterogeneity are thought to be important in controlling local diversity (Huston 1979, Rosenzweig 1995, Gray 2002, Leibold et al. 2004). Regional influences such as region size, degree of isolation and levels of speciation, adaptive radiation and evolutionary opportunity are thought to be important in determining the ultimate size of the available species pool (e.g. Wilson \& Hessler 1987, Wilson 1998, Gaston 2000, Witman et al. 2004, Rex et al. 2005). In marine diversity studies, such regional influences are often ignored, even though the connectedness of habi- tat patches within a region via larval dispersal will cause local and regional processes to interact (Leibold et al. 2004, Witman et al. 2004). The Antarctic continental shelf habitats present a unique context to test theories of ecological diversity because it is influenced on regional scales by isolation from the Antarctic Circumpolar Current, and on local scales by low temperatures and extreme seasonality in primary production (Page \& Linse 2002, Ducklow et al. 2006, Smith et al. 2006, Glover et al. 2008).

Taxonomic, biogeographic and macro-ecological studies have historically supported the view of a lowdiversity Southern Ocean, based largely on the apparent decline in diversity with latitude (e.g. Crame 2000). However, a number of recent field programs have recovered surprisingly long species lists of Antarctic benthic taxa, many new to science, suggesting that diversity may in fact be much higher than previously thought (Richardson \& Hedgpeth 1977, Gallardo et al. 1977, Gray 2001, Hilbig 2001, Clarke \& Johnston 2003, 
Hilbig 2004, Hilbig et al. 2006, Brandt et al. 2007). Unfortunately it has proved difficult to collect quantitative data on Antarctic benthic diversity that are comparable with other habitats (Gutt et al. 2004). The aim of this paper is to expand our knowledge of Antarctic biodiversity by examining polychaete species diversity from a new set of West Antarctic Peninsula (WAP) shelf samples, and assess whether Antarctic marine benthic diversity is relatively higher or lower than other deepwater low-latitude sites for which comparable data are available. An additional goal is to explore the impact of changes in food availability in the sediments on benthic diversity at a local scale in Antarctica.

The average depth of the Antarctic continental shelf is approximately $450 \mathrm{~m}$, and in places it is over $1000 \mathrm{~m}$ deep (Clarke \& Johnston 2003). The expanses of deep Antarctic shelf and deep basins result in over $90 \%$ of the Antarctic region being deeper than $1000 \mathrm{~m}$. The shelf benthic fauna thus relies on the sinking flux of particulate organic matter sinking from the euphotic zone, or advected from other areas, reminiscent of conditions in the deep sea (Smith et al. 1997, 2006). Furthermore, the Antarctic shelf is subject to intense variation in surface primary productivity as a result of extreme seasonality in photoperiod and sea-ice cover (Eicken 1992, Ducklow et al. 2006). Productivity, and, therefore, food availability to benthic heterotrophs, has been suggested to be one of the most important factors influencing diversity in soft-sediment marine environments (Rosenzweig 1995, Gray 2002). However, other environmental variables, including variations in temperature, salinity, depth, current energy, bottom-water oxygen and sediment type, can also influence diversity on local and regional scales (e.g. Grassle \& Maciolek 1992, Levin et al. 2001). The issue is further complicated by the non-equilibrium dynamics associated with disturbance and succession, where intermediate stages of succession can have elevated diversity in the absence of productivity changes (e.g. Connell 1978, Kukert \& Smith 1992, Snelgrove \& Smith 2002). Thus, diversity changes are difficult to ascribe solely to variations in productivity. In our region of study on the WAP shelf, productivity (as measured by benthic abundance, sediment oxygen consumption and sediment food quality) is higher at the innermost station relative to the 2 outermost stations (Mincks et al. 2005, Glover et al. 2008); we thus include in this study a preliminary test of the impact of this productivity change on species diversity in the Antarctic, albeit over a relatively small spatial scale.

At local scales, species diversity may include elements of both the total number of species (species richness) and the distribution of individuals amongst species (dominance versus evenness). Historically, rather few studies have investigated dominance in Antarctic soft-sediment benthic communities owing to a lack of quantitative sampling. In particular, the majority of samples addressing benthic faunal diversity have come from epibenthic sleds, trawls and semi-quantitative grab samples, where large mesh sizes were used for sieving and the abundances cannot be considered reliable. Previous studies of deep-sea sediment infauna have determined that mesh sizes of a maximum of $300 \mu \mathrm{m}$ are required to adequately sample polychaetes, and the results show very high local diversity, with low dominance (e.g. Hessler \& Sanders 1967, Grassle \& Maciolek 1992, Glover et al. 2002, Snelgrove $\&$ Smith 2002). Given the similarities in physical characteristics between the bathyal deep sea and the deep Antarctic shelf (low temperatures, absence of light, high pressure, reliance on advected or sinking flux of organic matter, and fine sediments) and potentially shared evolutionary history (e.g Thatje et al. 2005), we hypothesize similar levels of local diversity and dominance for our quantitative polychaete samples.

In summary, we present a new data set of marine benthic diversity from Antarctica, and assess the following hypotheses: (1) Antarctic shelf polychaete diversity and community structure are homogeneous across the WAP shelf and (2) polychaete species diversity as measured by both species richness and evenness is the same in deep Antarctic shelf environments as in lower-latitude sedimented bathyal environments.

\section{MATERIALS AND METHODS}

Sampling sites. Three study sites were sampled as a part of the multidisciplinary Food for Benthos on the Antarctic Continental Shelf (FOODBANCS) project, with 5 cruises over the period November 1999-March 2001 (Smith et al. 2008). For the purposes of this spatial study, only data from the last cruise in March 2001 are presented in this paper. Quantitative abundance data and seasonal trends for the entire macrofaunal component of the sampling program have already been presented in Glover et al. (2008).

The study area was located on the WAP shelf, which extends for approximately $1500 \mathrm{~km}$ from the Bellinghausen Sea near $75^{\circ} \mathrm{S}, 80^{\circ} \mathrm{W}$ to the northern tip of peninsula near $63^{\circ} \mathrm{S}, 60^{\circ} \mathrm{W}$. The shelf is approximately $200 \mathrm{~km}$ wide and averages approximately $500 \mathrm{~m}$ in depth. The 3 sampling stations (Stn A at 580 m, Stn B at $615 \mathrm{~m}$ and $\mathrm{Stn} \mathrm{C}$ at $566 \mathrm{~m}$ ) are located along a transect crossing the WAP shelf near Anvers Island (Fig. 1). These stations were selected as representative of regional conditions at the inner, mid and outer WAP shelf, spanning a distance of $100 \mathrm{~km}$ across the shelf (Smith et al. 2008). Stn A lies within a basin roughly $25 \mathrm{~km}$ across, whereas Stns B and C are located on 

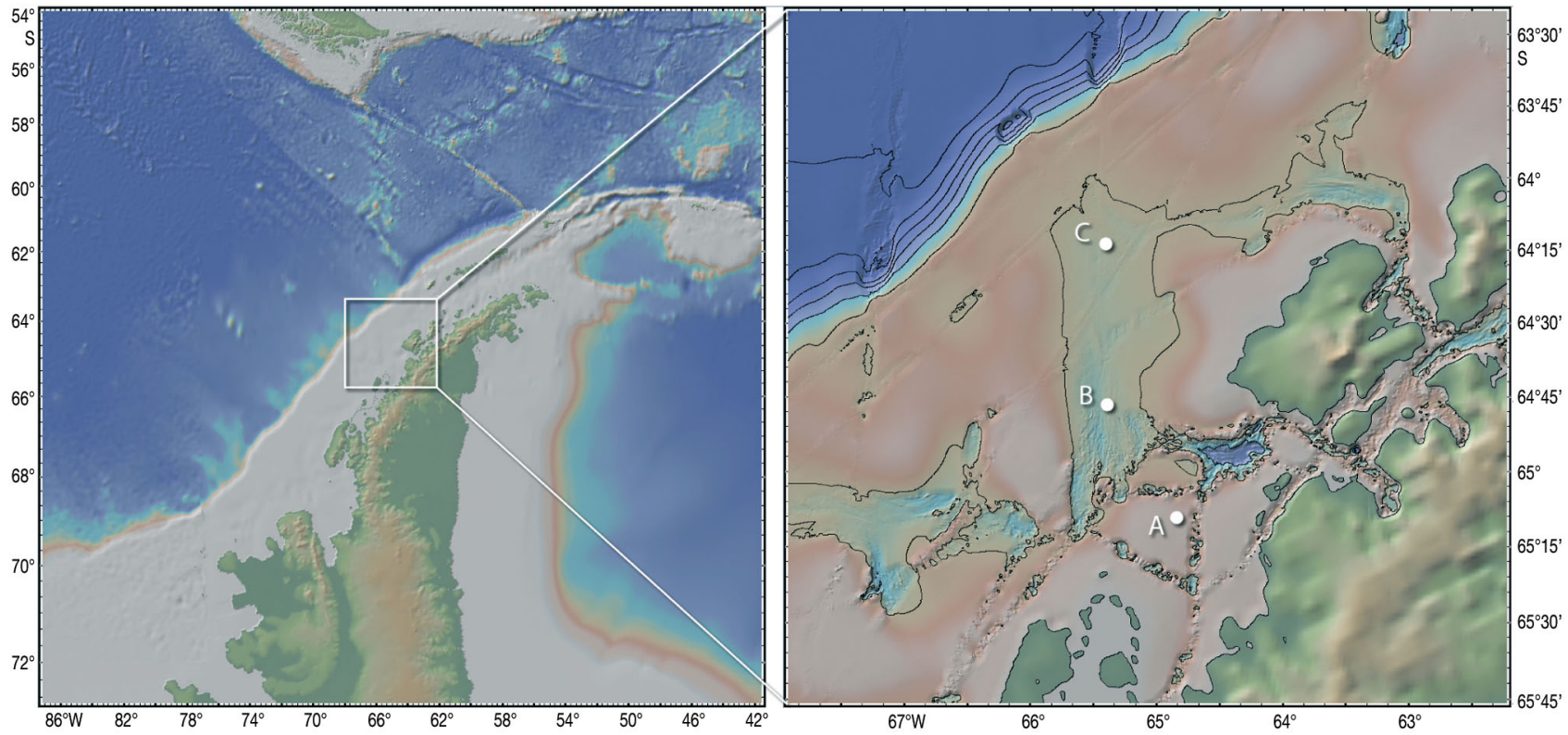

Fig. 1. Bathymetric map of the West Antarctic Peninsula. The enlarged region indicates the location of the sampling sites (Stns A, $\mathrm{B}$ and $\mathrm{C}$ ). Bathymetric contours are at intervals of $500 \mathrm{~m}$ (right-hand panel). Bathymetric map produced using GeoMapApp (www.geomapapp.org)

broad, flat portions of the continental shelf (Fig. 1). The study sites were characterised by fine-grained sediments and low topographic relief. A time-lapse camera and towed video system provided imagery of the seabed and showed no evidence of iceberg scour or resuspension of sediments during the $15 \mathrm{mo}$ of the study (Sumida et al. 2008; Fig. 2). A visible seafloor cover of phytodetritus was observed during the 2001 cruise (Smith et al. 2008; Fig. 2). A suite of environmental variables, including sediment porosity, chlorophyll a (chl a), enzymatically hydrolyzable amino acids (EHAA $;$ estimates bio-available fraction of the protein pool; cf. Mayer et al. 1995) and phytodetritus cover, were recorded along with macrofaunal and megafaunal abundance (summarised in Table 1). Stn A differed from Stns B and C in terms of megafaunal (Sumida et al. 2008) and macrofaunal (Glover et al. 2008) composition. Stn A was also characterised by 5 -fold higher sediment concentrations of chl $a$, slightly higher concentrations of EHAA and greater phytodetritus cover in March 2001 compared with Stns B and C (Mincks et al. 2005, Smith et al. 2008, Sumida et al. 2008).

Sample collection and processing. The samples were collected using a Bowers and Connelly megacorer, a type of multicorer, with twelve 10-cm diameter tubes. Previous studies indicate that this is currently the
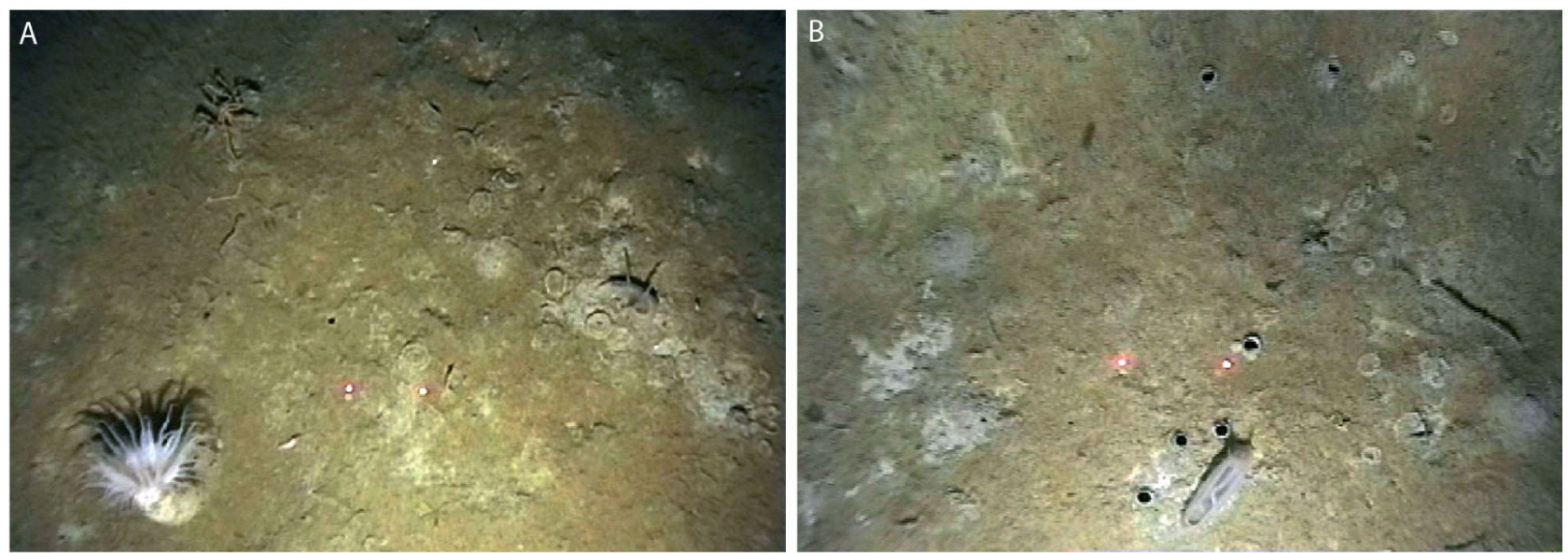

Fig. 2. Video-still images of the seafloor at (A) Stn A and (B) Stn B taken using a towed video camera in February 2001. Phytodetritus accumulation and consumption by elasipodid holuthurians is visible. Laser beams are $10 \mathrm{~cm}$ apart 


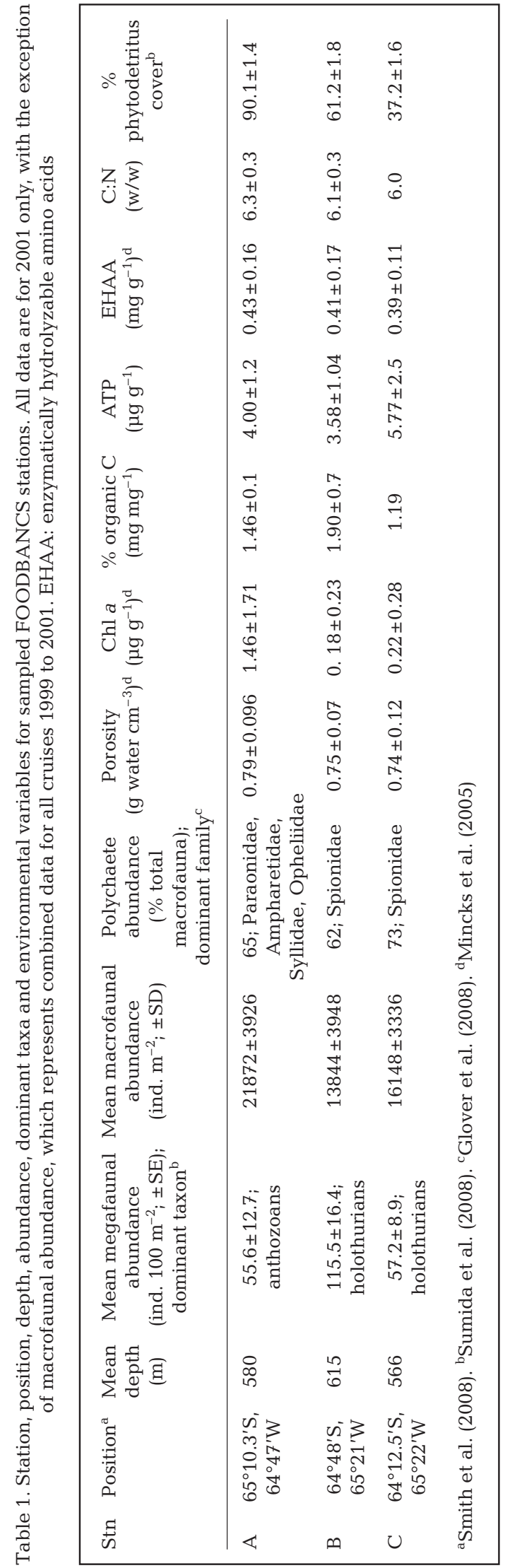

most quantitative sampler available for deep-sea studies (Shirayama \& Fukushima 1995, Gage \& Bett, 2005). Between 4 (Stn B) and 5 (Stns A and C) deployments were made at randomly selected coordinates within $1 \mathrm{~km}$ of the central point of each station. A single tube was taken for macrofauna analysis from each deployment replicate. Recovered megacore tubes were carefully extruded and sliced into $0-1,1-5$ and 5-10 cm layers at approximately in situ temperatures on deck. The entire layer for each slice was bulk-preserved in $10 \%$ borate-buffered formalin in seawater. In the laboratory, samples were carefully washed on a $300 \mu \mathrm{m}$ mesh and preserved in $80 \%$ ethanol. Samples were stained in Rose Bengal and quantitatively sorted under a dissecting microscope. Leica MZ6 and DM5000 stereo and compound microscopes were used to identify specimens. Named species identification (where possible) was carried out using published identification keys. In the case where a named species identification could not be obtained, the specimen was recorded as a morphospecies in a genus (e.g. Tharyx sp. A) or family (e.g. Ampharetidae sp. A). For every species found, a voucher specimen was erected. Images of these specimens were captured using a Zeiss V.20 and AxioCam $\mathrm{HRc}$, and a Leica DFC 480 dedicated camera system connected to the DM5000 (Fig. 3). A voucher worksheet was created for every such specimen, with a brief diagnostic description of the species, including drawings and photographs. Voucher worksheets for the reference collection have been made public on the Natural History Museum hosted website (http://polychaetes. info). The full species list including abundance counts is available in Table S1 in the supplement (www.int-res. com/articles/suppl/m428p119_supp.pdf).

Analysis of taxonomic composition and assemblage structure. The assemblage structure of the stations was assessed using an ordination approach to determine whether the stations were different in species composition, or representatives of a relatively homogenous shelf environment. Previously reported betweenstation differences in megabenthic (Sumida et al. 2008) and macrobenthic fauna (Glover et al. 2008) from FOODBANCS sites, as well differences in some environmental variables measured (Mincks et al. 2005, Smith et al. 2006, Smith et al. 2008), suggested an environmental change along the station transect from Stn A to Stns B and C. Because species are thought to have a unimodal distribution around their optimum (Jongman et al. 1987), a unimodal response-based correspondence analysis (CA) was chosen for ordination analysis (see Fig. 4). For completeness, a multidimensional scaling (MDS) analysis was also undertaken; results showed very similar patterns and are not included here. Polychaete assemblages were detected by CA using CANOCO software (ter Braak \& Smilauer 

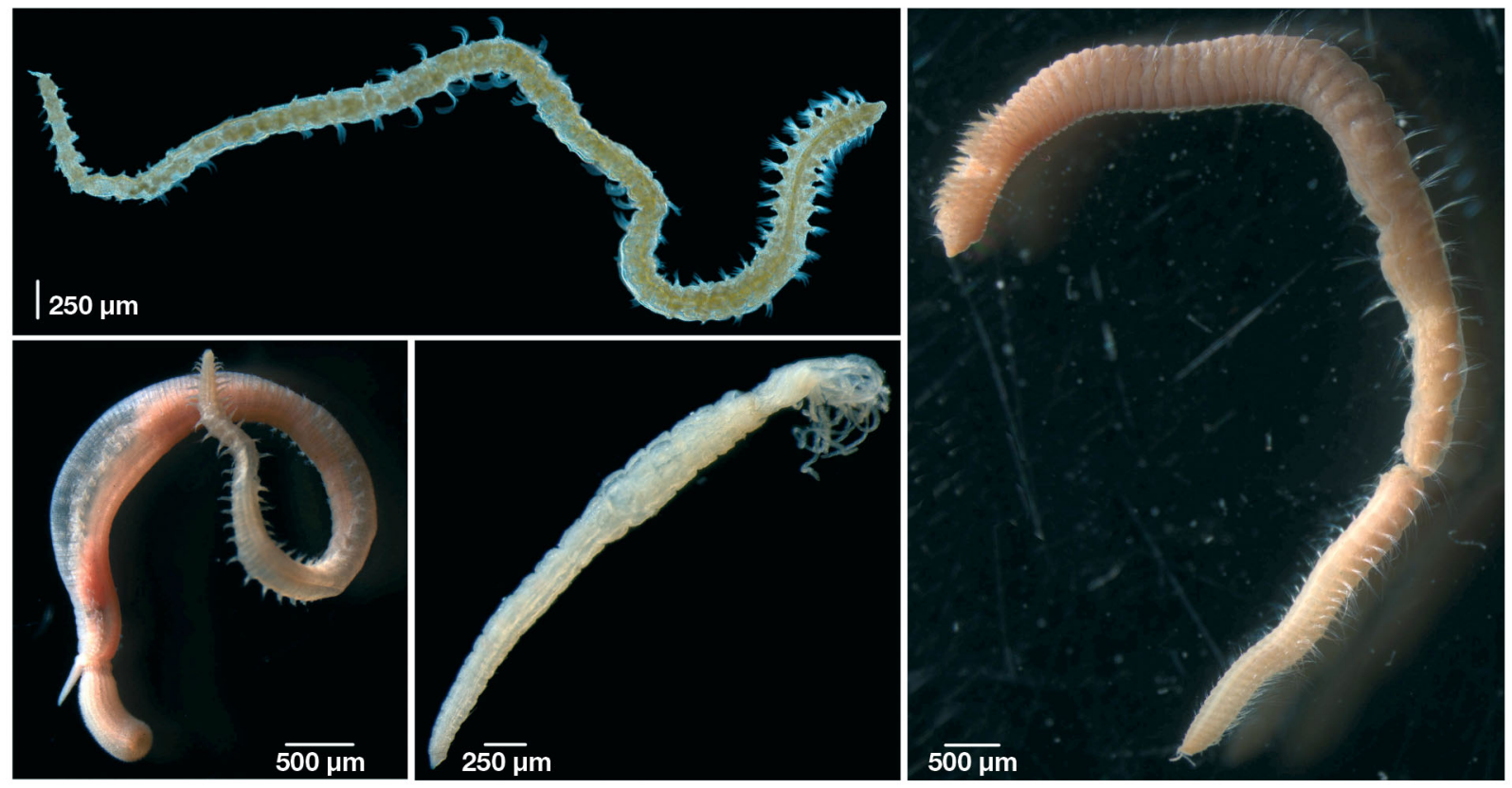

Fig. 3. Stereomicroscope images of dominant polychaetes at the FOODBANCS stations. Clockwise from top left: Aurospio foodbancsia, Aricidea cf. simplex, Euchone sp. B and Glycera cf. capitata

2002). All data were $\log _{10}(x+1)$-transformed to limit the influence of the most dominant species. The percentage composition of the top 5 numerically dominant species at each station was also determined and is presented in tabular form.

Environmental variables. As part of the FOODBANCS project, which was primarily concerned with measuring temporal changes on the Antarctic shelf, a number of environmental variables were collected from the 3 stations (e.g chl a, EHAA, microbial biomass [ATP concentrations], C:N ratios, sediment porosity and \% organic $C_{i}$ Mincks et al. 2005). The specific measurements relevant to our samples taken in February 2001 are provided in Table 1. As our spatial sampling size was quite low (3 stations), it was not statistically appropriate to use these environmental variables directly in the multivariate or regression analyses.

Analysis of species diversity. The concept of species diversity includes both species richness (the actual number of species) and the degree of dominance (or evenness). Most indices of diversity, calculated from quantitative samples, take into account some degree of both richness and dominance. Local diversity at each station was assessed by calculating the ShannonWiener diversity index $H^{\prime}[\log (\mathrm{e})]$ and Pielou's evenness index $J^{\prime}$ using the PRIMER package (Clarke \& Gorley 2006). We used the rarefaction approach (Sanders 1968), implemented in the package ECOSIM (Gotelli \& Entsminger 2000) and conducted on pooled samples per station, to study species diversity patterns independent of sample size, although as with the diversity indices, rarefaction is also influenced by dominance (Gage \& Tyler 1991, Gage \& May 1993). To study actual species richness independent of dominance effects, it is ideal to have a suite of samples where species counts are no longer increasing with sampling effort (i.e. are saturated); however, at all of our sites, and in published data from other sources, there was no evidence that this asymptote had been reached (see Fig. 5). However, extrapolation methods can be used to provide some estimate of richness, and there has been extensive discussion of their relative merits (e.g. Colwell \& Coddington 1994, Brose et al. 2003, Magurran 2004, O'Hara 2005, Walther \& Moore 2005). Here we follow the decision path for estimator choice developed by Brose et al. (2003). We used the Jackknife 2 (Jack2) and Chao1 estimators implemented using the Primer package (Clarke \& Gorley 2006). Jack 2 is considered to perform well for both even and uneven communities, and Chao1 is likely to provide a lower bound to species richness, producing only conservative estimates (O'Hara 2005).

To place our diversity estimates in a geographical and bathymetrical context, we collected and analysed published species diversity data from a range of deepsea and shelf marine benthic habitats (summarized in Table 5). Differences in sampling design, sampling gear, number of replicates, mesh size, sample handling, method of data analysis and reporting of data vastly reduced the suite of data sets that could be 
included in our analysis. We limited our choice of data to studies of polychaete diversity where the samplesize-independent measure of rarefaction was reported, or where original data sets were available for calculation of rarefaction curves, Jack2 and Chao1. We further limited our selection of data sets to those based on core or grab samples, eliminating studies that used sledge- or trawl-based data, which tend to poorly sample small infaunal taxa.

\section{RESULTS}

\section{Taxonomy}

A total of 78 species were identified from 1035 individuals and 14 samples, belonging to 27 different polychaete families. Of the 1035 individuals collected, $78 \%$ were identified to a named species, with $19 \%$ potentially new to science. Of the 78 species, only $35 \%$ could be identified to a named species, with $65 \%$ potentially new to science. The estimated number of species new to science $(65 \%)$ can only be interpreted as an upper limit in our samples - the actual figure is likely to be lower as some species were in too poor condition to be confidently identified beyond being different from anything else in the sample. A single species, discovered and described as new to science during the FOODBANCS program-Aurospio foodbancsia Mincks et al., 2009-was by far the most abundant species, representing $52 \%$ of all individuals examined in all samples combined.

\section{Polychaete assemblages}

At all stations, samples were heavily dominated by polychaetes of the family Spionidae, in particular by Aurospio foodbancsia (Fig. 3). This single species contributed $26 \%$ of the individuals at Stn A, 63\% at Stn B and $70 \%$ at Stn $C$ (Table 2). A more even distribution of individuals amongst species was observed at Stn A. Two species of Paraonidae, Aricidea cf. simplex Day, 1963 and Levinsenia cf. gracilis Tauber, 1879, contri- buted $9 \%$ each at $\mathrm{Stn}$ A. These species are thought to have cosmopolitan distributions, but probably represent species complexes for which genetic evidence is still lacking. A. simplex was very rare at $\operatorname{Stn} C$ and $L$. gracilis was completely absent at Stns B and C. The only species besides $A$. foodbancsia that was abundant at all 3 stations was the syllid Exogone cf. minuscula Hartman, 1953. The opheliid Ophelina cf. farallonensis Blake, 2000 was abundant at both Stns A and C, but rare at Stn B. All stations were characterised by large numbers of rare species. At Stn A, $83 \%$ of the species (46 species out of 55) were each represented by $<2 \%$ of the individuals; at Stn B, this was $81 \%$ (27 species out of 33), and at Stn C $76 \%$ (26 species out of 33).

Corresponcence analysis revealed the relatedness of the individual samples, the sampling stations and the species most important in driving the assemblage structure (Fig. 4). The samples showed clear separation between Stn A and Stns B and C (ANOSIM); however, there were differing degrees of heterogeneity within the stations. The broad scatter of samples from Stn A suggests high heterogeneity at this site, driven by variations in the abundances of Levinsenia, Aricidea, Asabellides, Notomastus, Laonice and Maldane (for clarity, only the generic names are provided in Fig. 4). With the exception of one outlier sample (B-757), the samples from Stns B and C are closely grouped because of the high dominance of Aurospio foodbancsia. Other abundant species at these stations included the lumbrinerid Paraninoe antarctica Monro, 1930 and the glycerid Glycera cf. capitata Örsted, 1843. The outlier sample from Stn B showed lower Aurospio abundance and higher abundance of Nothria, Anobothrus and Sternaspis. All of the Stn C samples were dominated by Aurospio and were tightly clustered. In summary, there was a considerable degree of heterogeneity in the WAP shelf region of interest. Stn A samples showed the highest heterogeneity, Stn B intermediate and Stn $\mathrm{C}$ the least (Fig. 4). In terms of species composition, there was a shift from the innermost station (A) to the outer 2 stations (B and $\mathrm{C}$ ), primarily driven by the increased abundance of subsurface deposit feeders at the innermost station, and reduced levels of dominance by the surface-deposit feeding $A$. foodbancisa.

Table 2. Top 5 dominant polychaete species found at each station. For each species, the percentage of the total number of individuals is given

\begin{tabular}{|lclclc|}
\hline Stn A & \% total & Stn B & \% total & Stn C \\
\hline Aurospio foodbancsia & 26 & Aurospio foodbancsia & 63 & Aurospio foodbancsia \\
Aricidea cf. simplex & 9 & Exogone cf. minuscula & 4 & Ophelina cf. farallonensis & 70 \\
Levinsenia cf. gracilis & 9 & Flabelligella sp. A & 4 & Glycera cf. capitata \\
Exogone cf. minuscula & 7 & Euchone sp. B & 3 & Paraninoe antarctica & 3 \\
Ophelina cf. farallonensis & 7 & Aricidea cf. simplex & 3 & Exogone cf. minuscula \\
\hline
\end{tabular}




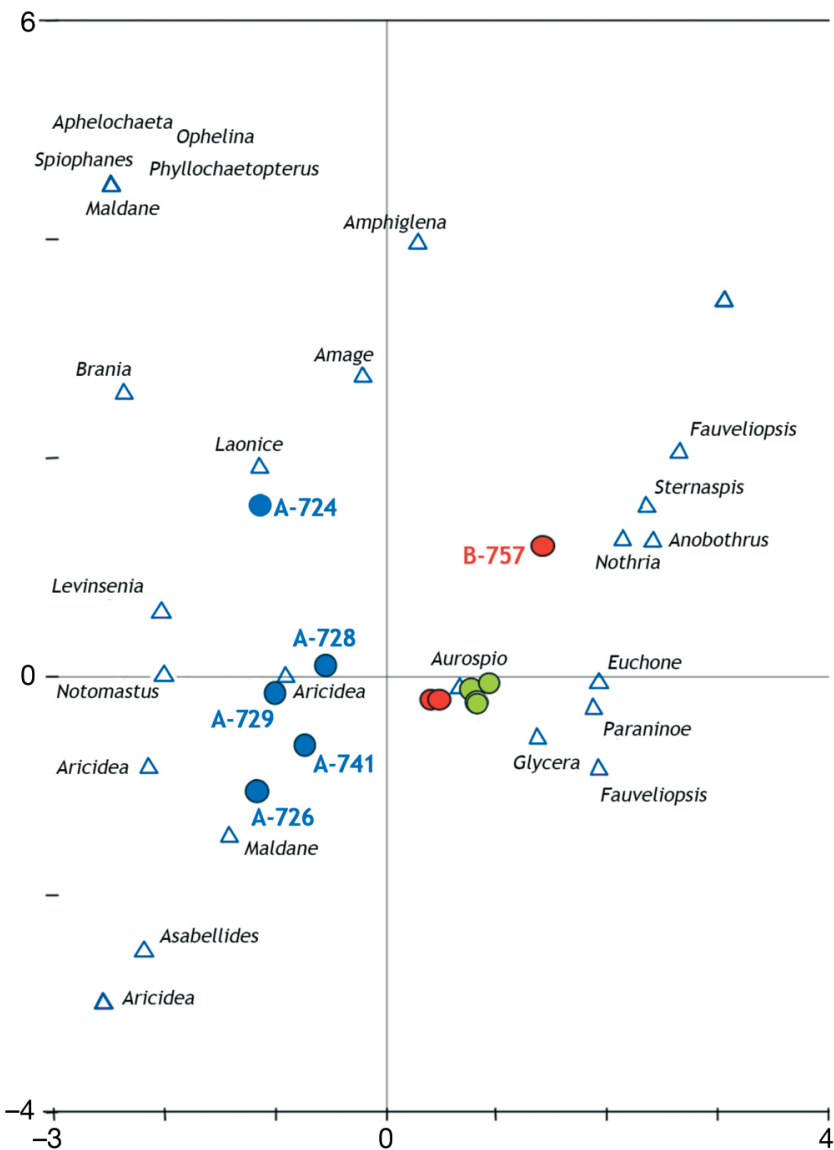

Fig. 4. Correspondence analysis (CA) depicting core samples as circles (Stn A,: blue; Stn B: red; Stn C: green). Species (triangles) are arranged in the same ordination space, providing an indication of the species that are likely to be driving the shifts in assemblage structure. Species are labelled (to genus), as are outlier samples from the main Aurospio group. Samples that lie close together are more similar in species composition; samples that lie far apart are dissimilar in species composition. Species that lie close to each sample have high abundances in that sample. For clarity, only species that contribute at least $25 \%$ of the abundance have been displayed, and only samples from the outliers and Stn A have been labelled

\section{Local diversity}

Species accumulation curves indicate that all sites were under-sampled (Fig. 5A). The highest accumulation rate of species with samples was at Stn A, the second highest at Stn B and the lowest at Stn C. A total of 60 species were recorded at Stn A, 35 at Stn B and 34 at Stn C (Table 3). Rarefaction analysis produced a similar result, indicating under-sampling even on pooled samples, although in relative terms Stn B rarefaction curves were closer to Stn A, driven by the slightly higher heterogeneity at that site (Fig. 5B). $H^{\prime}$ was highest at Stn A (2.5), dropping to 1.61 at Stn B and 1.3 at Stn C. Similar between-station changes occurred in the evenness index $\left(J^{\prime}\right)$ (which was lowest
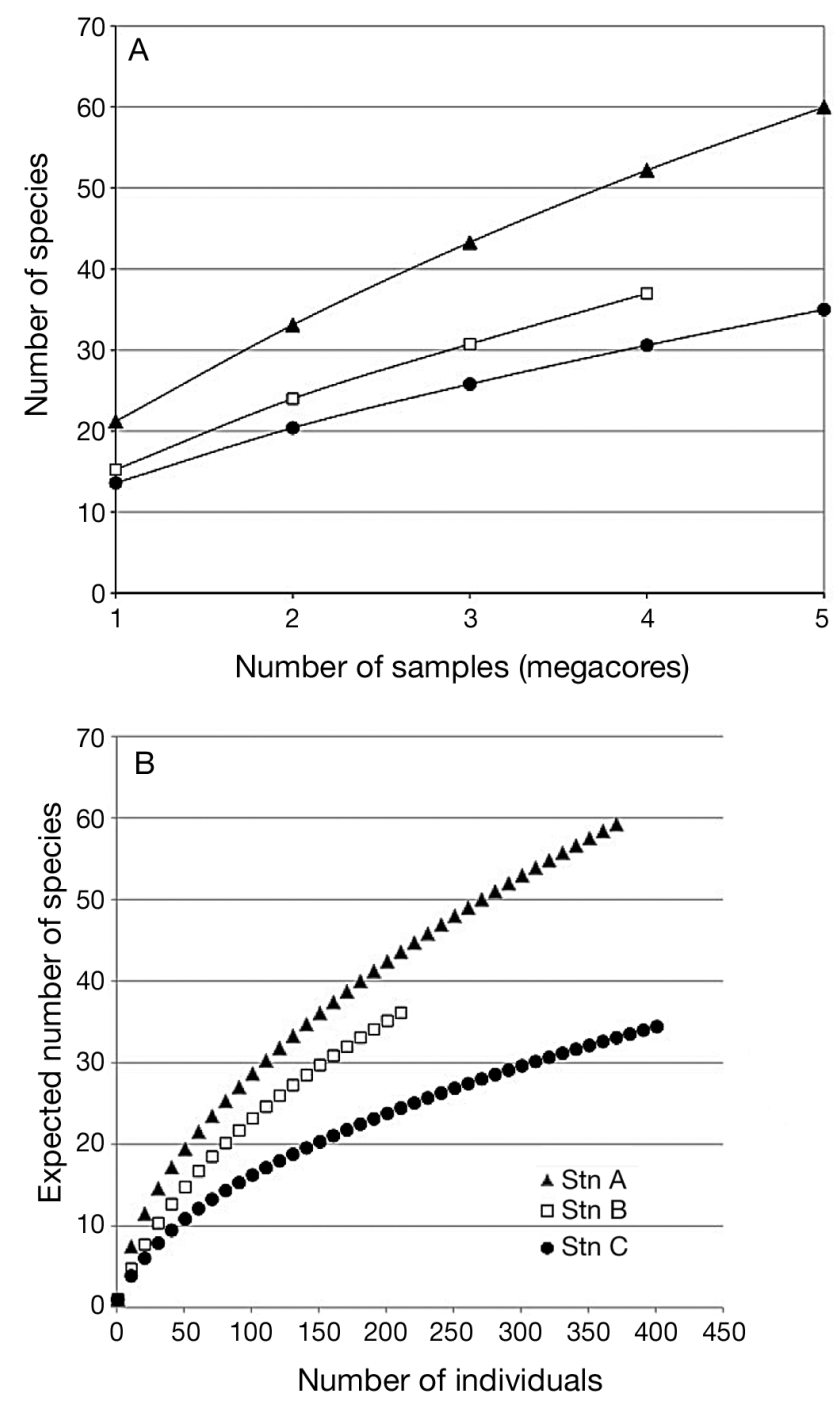

Fig. 5. (A) Species accumulation curve for FOODBANCS Stns A, B and C based on pooling of samples. (B) Rarefaction curves for FOODBANCS Stns A, B and C

at Stn C) and in the results from the rarefaction analyses (ES[200]) (Table 3, Fig. 3). The data suggest highest diversity in terms of species richness and evenness at Stn A, and lower diversity at Stns B and C, with Stn C lowest in some variables (e.g. ES[200]).

\section{Global comparisons}

To place the species diversity at the FOODBANCS stations in a global context, we compiled published estimates of local polychaete diversity based on sediment core or grab samples that used 300 to $1000 \mu \mathrm{m}$ sieve sizes (listed in Table 5) from a broad global suite of studies. Rarefaction analysis or published figures 
reveal a broad range of local species diversity at these sites, from ES(150) of $<20$ to $>60$ (Fig. 7). Although we made attempts to single out studies for which there would be less sample bias, the lower species diversity recorded at the Arctic sites is likely to be heavily influenced by the larger mesh size $(1000 \mu \mathrm{m})$. However, a clear trend is the lower diversity at the Antarctic bathyal stations compared with a broad range of abyssal plain samples (Fig. 7). This is apparently driven by the much higher dominance of certain species at the Antarctic shelf/bathyal stations, even though these sites may have a similar long 'tail' of rare species (Fig. 8). ES(150) at the Antarctic shelf/ bathyal sites was close to values reported for temperate bathyal regions. Within a given habitat, the abyssal and Arctic sites displayed the most consistent levels of rarefaction diversity, the former being high in diversity and the latter low (although probably driven lower in the Arctic by sampler bias); the Antarctic and temperate slope sites were the most variable.

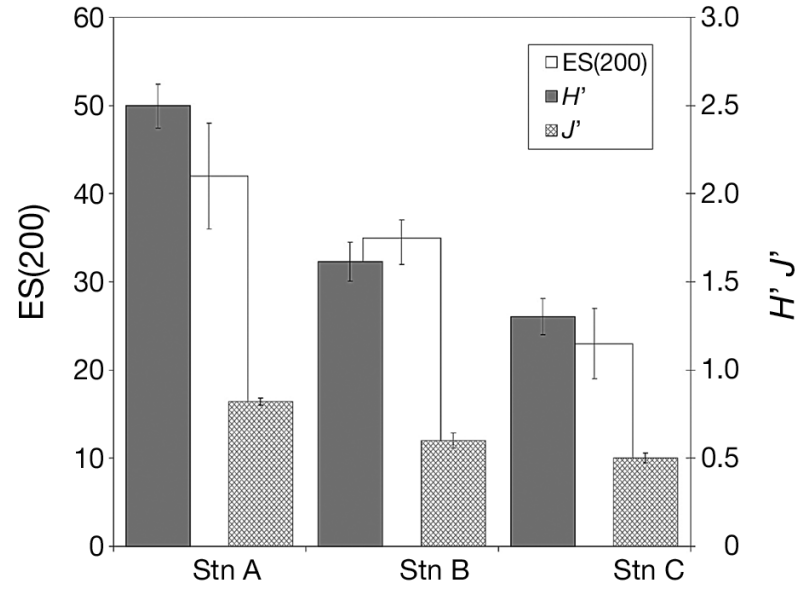

Fig. 6. Local polychaete species diversity at the FOODBANCS stations on the West Antarctic Peninsula shelf. The expected numbers of species from 200 individuals based on rarefaction analysis (ES[200]), Shannon-Wiener diversity index $\left(H^{\prime}\right)$ and Pielou's evenness $\left(J^{\prime}\right)$ are illustrated graphically. Error bars are $\pm \mathrm{SE}$

Table 3. Station, total area sampled, number of individuals $(\mathrm{n})$, density $\left(\mathrm{m}^{-2}\right)$, species richness $(S)$, Shannon-Wiener diversity index $\left(H^{\prime}\right)$, Pielou's evenness index $\left(J^{\prime}\right)$ and estimated number of species from 200 individuals based on rarefaction $(\mathrm{ES}(200))$. Means are presented $\pm \mathrm{SE}$, except in the case of ES, where $95 \%$ confidence intervals are given

\begin{tabular}{|lcccccrc|}
\hline Stn & $\begin{array}{c}\text { Area } \\
\text { sampled }(\mathrm{cm})\end{array}$ & $\mathrm{n}$ & $\begin{array}{c}\text { Density } \\
\left.\text { (ind. m }{ }^{-2}\right)\end{array}$ & $S$ & \multicolumn{1}{c}{$H^{\prime}$} & $J^{\prime}$ & $\begin{array}{c}\mathrm{ES}(200) \\
(95 \% \text { CI) }\end{array}$ \\
\hline A & 400 & 382 & $9575 \pm 832$ & 55 & $2.5 \pm 0.12$ & $0.82 \pm 0.02$ & $42(36,48)$ \\
B & 320 & 214 & $6656 \pm 1080$ & 35 & $1.61 \pm 0.11$ & $0.6 \pm 0.04$ & $35(32,37)$ \\
C & 400 & 420 & $10500 \pm 899$ & 34 & $1.3 \pm 0.1$ & $0.5 \pm 0.03$ & $23(19,27)$ \\
\hline
\end{tabular}
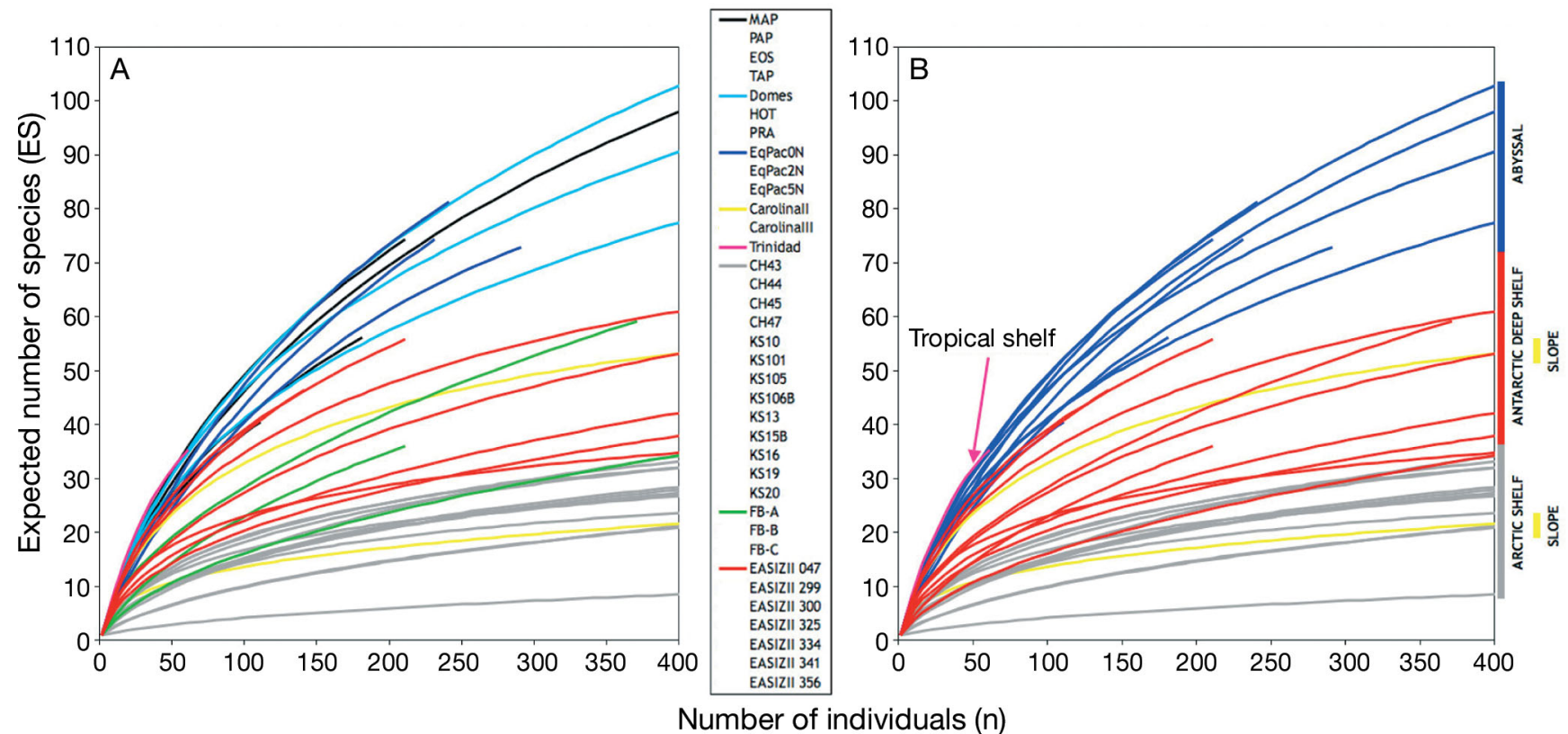

Number of individuals $(\mathrm{n})$

Fig. 7. Regional-scale variability in local benthic polychaete diversity estimated using rarefaction analyses, color-coded by (A) sampling programme and (B) habitat. Data are based on published studies cited in Table 4. Within this context, the FOODBANCS sites lie in the middle of the range for other published Antarctic shelf studies; they are lower in diversity compared with abyssal and tropical sites and higher in diversity relative to Arctic shelf sites 
Table 4. Estimates of polychaete diversity on a regional scale from deep-sea and high-latitude shelf environments made using comparable sampling devices (sediment corers). Comparative data are from Glover et al. (2001, 2002), Schaff et al. (1992), Hilbig (2001), Hilbig et al. (2006) and Feder et al. (2007). ES(150): expected number of species at a sample size of 150 individuals; $\mathrm{n}$ : number of individuals; $S$ : species richness; nd: no data

\begin{tabular}{|c|c|c|c|c|c|c|c|c|c|}
\hline $\begin{array}{l}\text { Locality } \\
\text { (habitat) } \\
\text { Site }\end{array}$ & $\begin{array}{l}\text { Depth } \\
\text { (m) }\end{array}$ & $\begin{array}{l}\text { Sampling } \\
\text { gear }\end{array}$ & $\begin{array}{l}\text { Mesh } \\
\text { size } \\
(\mathrm{mm})\end{array}$ & $\begin{array}{c}\text { Area } \\
\text { sampled } \\
\left(\mathrm{m}^{2}\right)\end{array}$ & $\begin{array}{l}\text { No. } \\
\text { replicates }\end{array}$ & n & $\begin{array}{l}\text { Density } \\
\text { (ind. } \mathrm{m}^{-2} \text { ) }\end{array}$ & $S$ & $\mathrm{ES}(150)$ \\
\hline \multicolumn{10}{|c|}{ N Pacific (abyss) } \\
\hline DOMES & 5100 & USNEL box core & 0.3 & 11.75 & 47 & 846 & 72 & 104 & 57.8 \\
\hline $\mathrm{ECHO}$ & 4800 & USNEL box core & 0.3 & 3.75 & 15 & 704 & 188 & 113 & 62.2 \\
\hline PRA & 4800 & USNEL box core & 0.3 & 4 & 16 & 1324 & 331 & 100 & 50.0 \\
\hline EqPac $0 \mathrm{~N}$ & 4300 & USNEL box core & 0.3 & 0.75 & 3 & 291 & 336 & 73 & 66.7 \\
\hline EqPac $2 \mathrm{~N}$ & 4400 & USNEL box core & 0.3 & 1 & 4 & 245 & 240 & 82 & 76.8 \\
\hline EqPac 5N & 4400 & USNEL box core & 0.3 & 0.75 & 3 & 240 & 320 & 76 & 69.6 \\
\hline \multicolumn{10}{|c|}{ NE Atlantic (abyss) } \\
\hline EOS & 4600 & USNEL box core & 0.5 & 2 & 8 & 214 & 143 & 74 & 62.8 \\
\hline PAP & 4800 & USNEL box core & 0.5 & 1.25 & 5 & 427 & 342 & 100 & 59.0 \\
\hline TAP & 5035 & USNEL box core & 0.5 & 0.54 & 3 & 186 & 258 & 57 & 51.4 \\
\hline \multicolumn{10}{|c|}{ NW Atlantic (slope) } \\
\hline CarolinaII & 850 & USNEL box core & $0.063,0.3$ & nd & & 2146 & 15776 & 69 & 39.0 \\
\hline CarolinaIII & 850 & USNEL box core & $0.063,0.3$ & nd & & 3888 & 36230 & 34 & 15.7 \\
\hline \multicolumn{10}{|c|}{ W Antarctic (deep shelf) } \\
\hline FB A & 580 & Megacore & 0.3 & 0.04 & 5 & 382 & 9500 & 58 & 35.5 \\
\hline FB B & 615 & Megacore & 0.3 & 0.032 & 4 & 214 & 6875 & 37 & 28.8 \\
\hline FB C & 566 & Megacore & 0.3 & 0.04 & 5 & 420 & 10350 & 34 & 20.0 \\
\hline EASIZII 047 & & Multibox corer & 0.5 & nd & & $\mathrm{n} / \mathrm{a}$ & $\mathrm{n} / \mathrm{a}$ & $\mathrm{n} / \mathrm{a}$ & 47.5 \\
\hline EASIZII 224 & 279 & Multibox corer & 0.5 & 0.168 & & 186 & 1107.1 & 53 & 48.0 \\
\hline EASIZII 299 & 212 & Multibox corer & 0.5 & 0.168 & & 886 & 5273.8 & 73 & 34.0 \\
\hline EASIZII 300 & 423 & Multibox corer & 0.5 & 0.168 & & 909 & 5410.7 & 53 & 24.5 \\
\hline EASIZII $325^{a}$ & 829 & Multibox corer & 0.5 & 0.168 & & 676 & 4023.8 & 53 & 26.5 \\
\hline EASIZII 326 & 625 & Multibox corer & 0.5 & 0.168 & & 504 & 3000 & 60 & 34.0 \\
\hline EASIZII 341 & 428 & Multibox corer & 0.5 & 0.168 & & 499 & 2970 & 65 & 42.3 \\
\hline EASIZII 345 & 218 & Multibox corer & 0.5 & 0.168 & & 497 & 2958.3 & 39 & 26.5 \\
\hline EASIZII 356 & 120 & Multibox corer & 0.5 & 0.168 & & 1076 & 6404.8 & 44 & 26.0 \\
\hline EASIZII 188 & 225 & Multibox corer & 0.5 & 0.12 & & 180 & 1500 & 49 & 45.5 \\
\hline \multicolumn{10}{|c|}{ Arctic (shelf, Chukchi Sea) } \\
\hline KS 105 & 25 & van Veen grab & 1 & 0.5 & 5 & 2057 & 4356 & 61 & 28.0 \\
\hline $\mathrm{CH} 45$ & 43 & van Veen grab & 1 & 0.5 & 5 & 794 & 750 & 41 & 26.0 \\
\hline $\mathrm{CH} 43$ & 18 & van Veen grab & 1 & 0.5 & 5 & 714 & 1564 & 34 & 19.9 \\
\hline KS 14 & 22 & van Veen grab & 1 & 0.5 & 5 & 302 & 640 & 30 & 23.4 \\
\hline KS $106 b$ & 51 & van Veen grab & 1 & 0.5 & 5 & 6938 & 28450 & 68 & 29.0 \\
\hline KS 21 & 36 & van Veen grab & 1 & 0.5 & 5 & 232 & 472 & 14 & 12.3 \\
\hline KS 16 & 25 & van Veen grab & 1 & 0.5 & 5 & 910 & 1936 & 44 & 27.0 \\
\hline KS 10 & 12 & van Veen grab & 1 & 0.5 & 5 & 1412 & 2972 & 58 & 27.0 \\
\hline $\mathrm{CH} 47$ & 47 & van Veen grab & 1 & 0.5 & 5 & 630 & 1328 & 34 & 22.5 \\
\hline $\mathrm{CH} 44$ & 32 & van Veen grab & 1 & 0.5 & 5 & 2010 & 4700 & 34 & 20.0 \\
\hline KS 20 & 38 & van Veen grab & 1 & 0.5 & 5 & 4134 & 8896 & 56 & 17.0 \\
\hline KS 15 & 17 & van Veen grab & 1 & 0.5 & 5 & 1382 & 2852 & 49 & 24.0 \\
\hline KS 101 & & van Veen grab & 1 & 0.5 & 5 & 6132 & 12736 & 58 & 23.0 \\
\hline KS 19 & 34 & van Veen grab & 1 & 0.5 & 5 & 4436 & 9116 & 51 & 16.0 \\
\hline
\end{tabular}

Where data were available, we made estimates of total species richness using the Jack2 and Chao1 estimators (Fig. 8). It should be noted that all the studied sites were under-sampled, so there is a great deal of uncertainty in these estimators. Nevertheless, some trends were apparent. The innermost Antarctic shelf stations (B and C) were characterized by lower total species richness compared with $\mathrm{Stn}$ A, which rivalled other temperate and tropical deep-sea abyssal sites for total richness. It should be noted that separate analyses (not included here) that included the pooling of data from Stns B and C produced diversity levels at the B/C 'province' that rivalled Stn A for diversity. The highest total species richness by these measures is reported for tropical abyssal stations, the lowest at the Antarctic shelf stations and a disturbed site in the temperate 


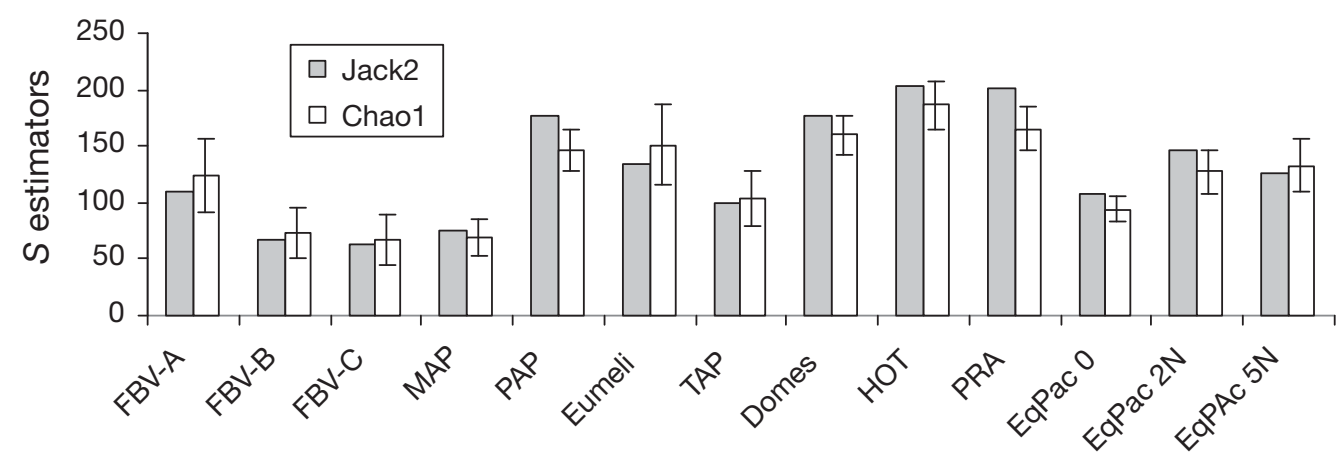

Fig. 8. Species richness $(S)$ estimators for FOODBANCS Stns A, B and C (FBV-A, FBV-B and FBV-C) and contrasting deep-sea sites for which raw data sets were available and suitable for analysis

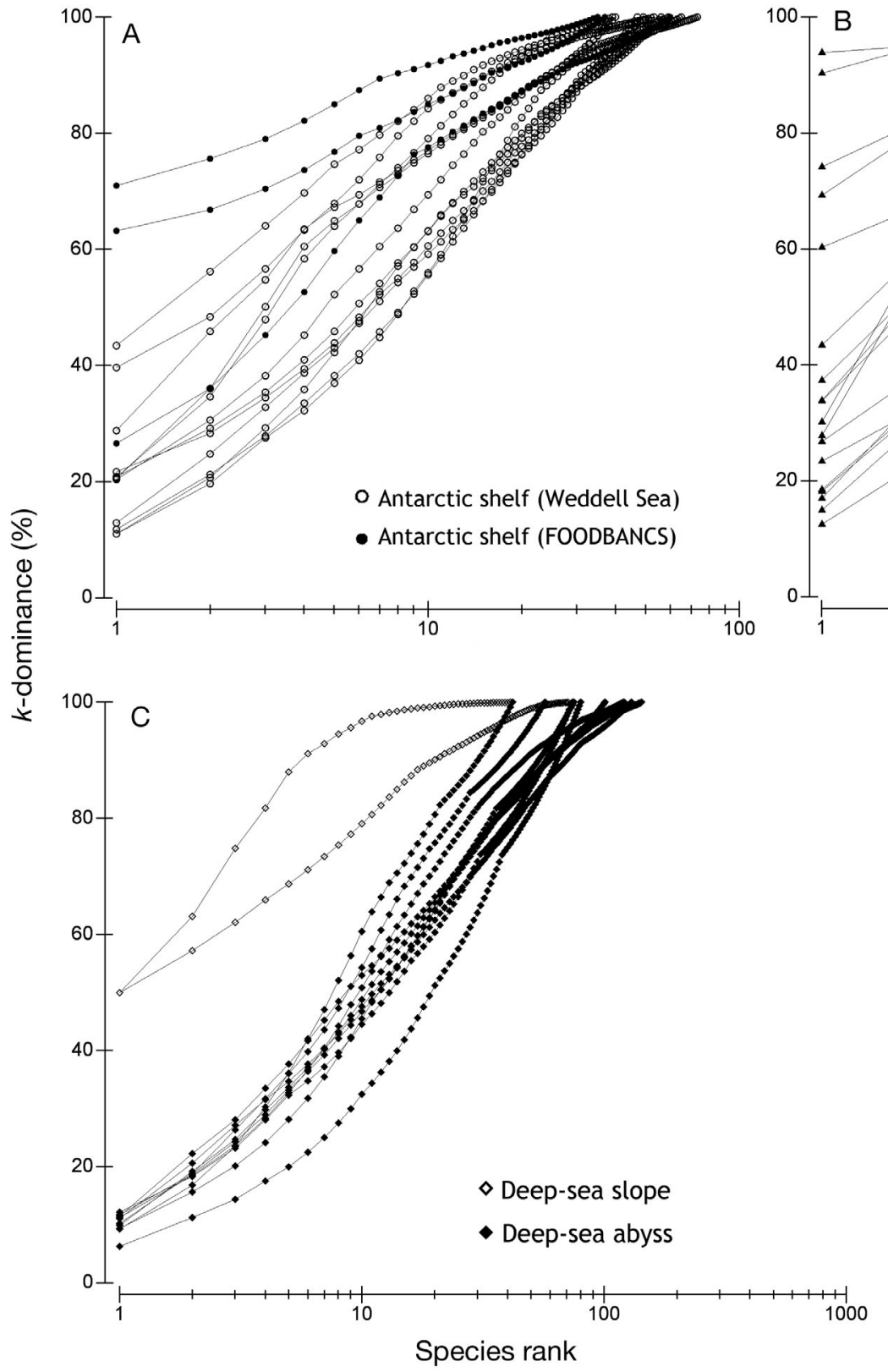

Fig. 9. $k$-dominance curves for (A) Antarctic shelf and slope sites, (B) Arctic sites and (C) bathyal and abyssal deep-sea sites. Arctic and Antarctic sites exhibit a broad range of dominance distributions; abyssal sites are uniformly low in dominance 
Atlantic abyss (Madeira Abyssal Plain). To investigate the global distribution of dominance/evenness at deep-sea sites, we also calculated $k$-dominance curves (Fig. 9). In general, abyssal stations showed consistently low dominance whereas high-latitude bathyal and shelf stations showed high levels of dominance.

\section{DISCUSSION}

\section{Polychaete community structure on the WAP shelf}

When comparing the 3 FOODBANCS stations (A, B and $\mathrm{C}$ ) in terms of polychaete community assemblages, polychaete species diversity and measurements of sediment food availability (chl a) (Mincks et al. 2005, Smith et al. 2008), there is one unifying theme. The Stn A community is more heterogeneous, has higher species richness, higher evenness and apparently greater quantities of labile food material (measured by $\%$ organic $\mathrm{C}$ and $\mathrm{chl}$ a) for deposit feeders in the sediment compared with Stns B and C, which exhibit similar values for most variables (Table 1). However, there was no substantial difference in ATP, C:N ratios, sediment porosity or quantities of EHAA between the stations (Table 1). Nevertheless, it seems highly likely that this shift in community structure across the WAP shelf is driven by these variables and associated with a change in productivity; in particular, the increased abundance of subsurface deposit-feeding polychaetes at Stn A is suggestive of fundamental changes in the characteristics of the sediments, which may be related to the topographic focusing of organic material in the basin surrounding Stn A. This pattern is also in agreement with trends detected for the macrofauna as a whole (Glover et al. 2008). Recent publication of longterm data sets (1995 to 2006) of WAP productivity (Vernet et al. 2008) provides supporting evidence for this change across the WAP shelf region, with higher production observed close to our inshore Stns A and B (900 to $1000 \mathrm{mg} \mathrm{C} \mathrm{m}^{-2} \mathrm{~d}^{-1}$ ) compared with lower levels ( $\sim 670 \mathrm{mg} \mathrm{C} \mathrm{m}^{-2} \mathrm{~d}^{-1}$ ) close to our Stn C. These differences in surface productivity are related to sea-ice dynamics and the formation of a shallow mixed layer in surface water (see Vernet et al. 2008 for discussion).

Correspondence analysis (Fig. 4) revealed that the polychaete assemblages from Stns B and C formed a similar but not entirely homogenous group (ANOSIM, $\mathrm{R}=0.51, \mathrm{p}=0.016$ ), whilst Stn A was composed of a different assemblage (ANOSIM, $\mathrm{R}=0.87, \mathrm{p}=0.008$ ). Video surveys of megafauna (Sumida et al. 2008) showed a similar pattern. The most striking result in terms of the community structure was the very high abundance of Aurospio foodbancsia at all stations, but particularly at Stns B and C, which caused them to cluster closely (Table 2, Fig. 4). Even at the most species-diverse station (A), A. foodbancsia constituted $26 \%$ of total polychaete abundance, increasing to $63 \%$ at Stn B and $70 \%$ at Stn C. The fact that A. foodbancsia, which is arguably the most abundant macrofaunal species in the WAP shelf region (when small mesh sizes are used), was new to science prior to the FOODBANCS project illustrates how the smaller macrofauna on the shelf is poorly sampled around the Antarctic Peninsula, with much basic taxonomy remaining to be done.

The high dominance of Aurospio foodbancsia on our WAP shelf sites seems to indicate an opportunistic response to recent disturbance. However, we did not detect significant shifts in the abundance of $A$. foodbancsia over the course of the 15-mo FOODBANCS study (Mincks et al. 2009), and the observed frequencies of ovigerous females over time were not consistent with reproductive variability, as might be expected if the species was adapted to respond to rapid shifts in food availability (Mincks et al. 2009) or to disturbance from iceberg scour at shallower depths. Interestingly, we found that a large percentage of specimens were parasitized by an unknown turbellarian (Mincks et al. 2009), which may be a consequence of the very high population densities achieved by the species on the WAP shelf.

Stn A showed not only marked dissimilarity in species composition from Stns B and C, but also a higher level of between-sample heterogeneity. This species mosaic at Stn A was mainly driven by shifts in the abundance of 3 species of Paraonidae: morphospecies Aricidea sp. H, Aricidea cf. simplex and Levinsenia cf. gracilis. Of these, both $L$. gracilis and A. simplex are considered cosmopolitan species more often confined to deeper water (Blake 1996). It is quite probable, but untested genetically, that these species represent complexes of cryptic species and that the Antarctic shelf forms may be different species. Given the limitations of our morphological study, we have no evidence to support any potential recent genetic exchanges with populations of similar morphospecies in other ocean basins. However, genetic data from a recent study of Aurospio foodbancsia does indicate a small, almost undetectable morphological change from deep-water Aurospio dibranchiata to shelf-depth A. foodbancsia (Mincks et al. 2009).

Overall, Paraonidae was the most species-rich family at our WAP sites with 10 species. Paraonids are considered subsurface deposit feeders, and they drive much of the functional change in the polychaete community from Stns B and C, where they are rare and the community is dominated by surface deposit feeders, to Stn A, where they are much more abundant (Fig. 4). Maldanid polychaetes were also 
found only at Stn A, represented mainly by Maldane sarsi. These animals are considered 'conveyor belt' species, which feed head-down in sediments, rapidly subducting organic material down around their burrows (Graf 1992). The abundance of subsurface deposit feeders at Stn A is consistent with enhanced productivity and food availability in the sediment, as evidenced by higher values of phytodetritus cover and higher concentrations of chl $a$ in the sediments at relative to Stns B and C (Mincks et al. 2005, Smith et al. 2008), most likely caused by higher overlying productivity (Vernet et al. 2008) and/or topographic focusing of sediment.

\section{Polychaete species diversity on the Antarctic shelf}

By any estimators of species accumulation (Fig. 5), the stations in this study are under-sampled and as such it is impossible to accurately predict polychaete species diversity for the entire WAP shelf region. This is a common problem in studies where samples are from quite small sediment cores relative to the vast expanses of the sedimented shelf or deep-sea habitat that they are attempting to describe. Nevertheless, using estimators of accumulation, evenness and comparing diversity normalised to random subsamples of individuals, it is possible to make some valid comparisons, both within this study and between this and other previous published diversity data sets.

At a local level, a clear trend is apparent for the WAP shelf region we have studied. There is a decrease in species diversity from Stn A, which is closest to the Antarctic mainland, to Stn C, which is furthest away (Figs. $1 \& 6$ ). We have only limited environmental data that correlate with this trend, with the exception of the apparent increase in sediment chl a content and March 2001 phytodetritus cover at Stn A versus Stns B and C. However, there is no obvious environmental gradient between Stns B and C supporting a diversity decline, other than simply distance from the mainland. Although our sample size is low and we are unable to make rigorous statistical comparisons, we conclude that there is tentative support for a relationship between species diversity and productivity at our sites, with the highest diversity site also having the highest apparent productivity, measured by benthic macrofaunal abundance (Glover et al. 2008) and food availability in the sediment (Mincks et al. 2005). This is also supported by the evidence from surface-water measurements of productivity, which show a clear enhancement of production further inshore close to our Stns A and B (Vernet et al. 2008). Of course we cannot exclude the possibility that other unmeasured variables are also significant.
Given that more general ecological theory suggests a unimodal relationship between productivity and diversity (e.g. Huston 1979, Rosenzweig 1995), our results suggest that polychaete diversity on the WAP shelf may be food limited, and that the sites lie on the 'increasing' phase of this monotonic curve. It is interesting to compare this clear spatial variability in diversity and species composition on the WAP shelf with the almost complete lack of temporal variability in response to dramatic changes in the fluxes of organic matter between Antarctic seasons (Smith et al. 2006, Smith et al. 2008, Glover et al. 2008 and references in the same volume). Although species-level analysis has only been carried out for the single time-point analysed in the present study, the apparent consistency of macrofaunal and megafaunal community compositional change across the FOODBANCS time series lends weight to the spatial differences observed between Stns A and B/C. We can at least conclude that the unusual diversity and compositional pattern at Stn A is not a result of a recent opportunistic recruitment in response to a seasonal input of food (cf. Mincks \& Smith 2007).

The second clear pattern is the apparent high levels of dominance, or low levels of evenness, for the Antarctic shelf stations we have examined (Figs. 6 \& 9). In general, high-latitude deep-shelf environments appear to have higher dominance than lower-latitude abyssal environments (Fig. 9). High dominance has long been recognized as characteristic of communities under stresses such as disturbance (Magurran 2004) and unpredictability in environmental conditions (Preston \& Preston 1975). The FOODBANCS project found a strong seasonal and even stronger interannual variability in $\mathrm{chl} a$ and particulate organic $\mathrm{C}$ flux to the seafloor (Mincks et al. 2005, Smith et al. 2008), suggesting unpredictability in food supply. However, little such variation was found in the sediments, where food appears to accumulate and remain accessible to the benthos throughout the year as a 'foodbank' (Mincks et al. 2005, Smith et al. 2006, 2008). We cannot therefore ascribe the high level of dominance to unpredictability in food supply. Other possibilities include ice scour or sediment resuspension, but the FOODBANCS stations are well below the maximum depth of ice scour in this region, and there is no evidence from time-lapse cameras (deployed from December 1999 to March 2001 at Stn B) or video surveys during 5 cruises that these processes occur at the FOODBANCS stations.

High dominance has been observed in some other Antarctic datasets (Gambi et al. 1997, Sicinski \& Janowska 1993, Raguá-Gil et al. 2004). At the FOODBANCS sites, high dominance by elasipodid holothurians was also reported in megafaunal studies (e.g. Sum- 
ida et al. 2008), but this is common in most deep-sea studies of holothurians. Gambi et al. (1997) noted high dominance of polychaetes from shallow depths of the Ross Sea. During the sampling of 14 stations, they collected 5768 individuals belonging to 77 species, but just 6 species accounted for $76 \%$ of the total abundance. Similarly, Sicinski \& Janowska (1993) noted high dominance in polychaete assemblages from Admiralty Bay on the WAP, with $70 \%$ of the individuals belonging to just 5 dominant species.

\section{Antarctic benthic diversity in a regional and global context}

There is a large body of literature addressing macro-ecological gradients in diversity, in particular the apparent declines in diversity with increasing latitude in terrestrial habitats, and the drivers behind such declines (e.g. Pianka 1966, Rohde 1992, Gaston 2000). For marine benthic ecosystems, the presence of a latitudinal decline in diversity is much more controversial. For example, several studies have both supported the idea of reduced marine diversity in the Antarctic (e.g. Dell 1965, Dayton 1990, Crame 2000, Rex et al. 2005) whereas numerous studies have challenged it (Gallardo et al. 1977, Richardson \& Hedgpeth 1977, Gray 2001, Hilbig 2001, Clarke \& Johnston 2003, Hilbig 2004, Hilbig et al. 2006, Brandt et al. 2007). A broad meta-analysis of these diversity patterns is beyond the scope of the present study, but our data are of relevance to the debate. In particular, we believe it is essential to have an adequate understanding of the sample biases in any study. For example, in this study we have uncovered a potential wealth of species new to science-some of them highly abundant - in the small sediment infauna that is retained on a $300 \mu \mathrm{m}$ sieve. This is probably a result of using a hydraulically dampened megacorer that is able to collect virtually undisturbed long cores of sediment. In contrast, more widely used trawl or epibenthic sledge samplers will collect over a much broader area, but miss small infauna that can be collected by the corers. The major methodological issues of comparative diversity studies have been well discussed (e.g. Gray 2002). The main issues are with differences in sampling design (gear, effort and mesh size) and we are well aware that these may influence our results. In our study we have been careful to include only infaunal sampling and to at least a sediment depth of $10 \mathrm{~cm}$, where the majority of macrofauna (>85\%) is found (Shaff et al. 1992, Glover et al. 2001, Glover et al. 2002, G. Paterson et al. unpubl. data).

The data included in our analyses suggest that the local diversity (measured by rarefaction, dominance indices and species richness estimators) is broadly similar across the WAP shelf, Weddell Sea shelf and temperate bathyal regions (Figs. 7 to 9). Arctic shelf diversity has often been suggested to be low relative to similar Antarctic environments, although data to the contrary have recently been reported (e.g. Piepenburg 2005, Wlodarska-Kowalczuk 2007). We compared polychaete diversity on the Antarctic shelf (present study and Weddell Sea sites) with data from the shallow Chukchi Sea (Feder et al. 2007) and found similar or slightly lower species richness at the Arctic sites (Fig. 7) based on rarefaction. Arctic communities also exhibited low evenness, similar to Antarctic communities. This comparison must be viewed with some caution because of the use of a larger $1 \mathrm{~mm}$ mesh size at shallower Arctic sites (typical of many shallowwater studies) relative to the $300 \mu \mathrm{m}$ mesh used in ours and other deep-water studies. However, infaunal organisms also tend to be larger in shallow waters, and representative samples may thus be obtained using different mesh sizes in each habitat. In a comparable study of diversity at Arctic and Antarctic marine inlets (where disturbance from ice-rafted debris is likely to be high), similar levels of local and point-scale diversity were reported in both systems (Wlodarska-Kowalczuk et al. 2007). Our Stn C values are comparable to those of Wlodarska-Kowalczuk et al. $(2007)(\mathrm{ES}[50]=10.7 \pm 3.4,9.7 \pm 4.2$ and 10.5 \pm 4.9$)$, whereas Stns A and B are higher in diversity, so the lower limits of the range of diversity values on the Antarctic shelf may overlap with the upper range of values in the Arctic.

Abyssal plain sites, both temperate and tropical, generally show higher diversity than Antarctic sites based on rarefaction, richness estimators and evenness (Figs. 7 to 9). However, species richness at WAP Stn A approaches the lower limits of values for abyssal sites, as measured by rarefaction (Fig. 7), and is equivalent based on Chao1 and Jack2 (Fig. 8). Dominance can influence rarefaction results (Gray 2000); thus, Chao1 and Jack2 may be more informative in this situation. WAP Stns B, C and other shelf and bathyal Antarctic sites showed lower species richness than temperate and tropical abyssal plains. Abyssal samples were collected using box cores with a greater surface area than the megacore used in the Antarctic studies, which may have influenced estimates of species richness given the steepness of the rarefaction curves. However, abundances were also much higher at Antarctic sites (Table 4), which may have alleviated some of the bias due to the smaller sampled area. For example, at the DOMES site in the abyssal Pacific, the sampling area was approximately 100 times as large as the sample area for the 3 FOODBANCS stations, but the number of specimens was approximately the same and 
the number of species recorded at the FOODBANCS sites was approximately $25 \%$ lower (Table 4 ). Schüller et al. (2009) also reported comparable levels of polychaete diversity at Antarctic sites sampled during the ANDEEP III expedition relative to abyssal Altantic mesotrophic and oligotrophic sites (Cosson-Sarradin et al. 1998), although sampling methods again differed between studies. Rarefaction estimates from these studies also correspond well with our data and those from the EASIZ study (Hilbig 2001), but are lower than those reported for other temperate and tropical abyssal sites.

Dominance levels also varied between Antarctic and abyssal sites, with the single-most abundant species typically comprising only 7 to $12 \%$ of total abundance in the abyss (Grassle \& Maciolek 1992), in contrast to the much higher dominance observed in the Antarctic and Arctic shelf sites (Feder et al. 2007, present study). Gray et al. (1997) also concluded that evenness in the deep sea is higher than in shallower coastal environments. Extensive polychaete data sets from the recent ANDEEP expeditions to the Weddell Sea shelf and slope and Southern Ocean abyssal plain are also consistent with observations of high evenness at abyssal sites relative to Antarctic shelf sites (Schüller \& Ebbe 2007, Schüller et al. 2009). Antarctic shelf and slope polychaetes thus appear to approach other temperate and tropical bathyal/abyssal environments in diversity, but in general species richness is slightly lower and dominance is much higher.

In a re-examination of data from temperate deep-sea and shelf sites (Levin et al. 2001), individual rarefaction and species accumulation curves suggested that the deep sea supports higher diversity than the continental shelf. Brey et al. (1994) also compared diversities of deep-sea isopods, gastropods and bivalves collected from the Weddell Sea (500 to $2000 \mathrm{~m}$ ) with data published by Rex et al. (1993) for deep-sea tropical Atlantic using the rarefaction method. They concluded that at least for the taxa investigated, there was no latitudinal decline in deep-sea benthic diversity. However, these findings have been criticised owing to the much larger area sampling scale in the Weddell Sea compared with the deep tropical Atlantic (Rex et al. 1997).

Although variables such as local food availability may play an important role in structuring local diversity, regional influences are also expected to be important in Antarctica. It has been argued that regional diversity influences the pool of available species and can therefore impact local diversity if local communities are not species saturated (Leibold et al. 2004, Witman et al. 2004). Gutt et al. (2004) concluded that diversity of macrofauna from the Antarctic shelf is only intermediate in comparison with other tropical and temperate habitats and only 'slightly' higher than in the Arctic, a finding that at local scales is consistent with our results. The formation of the Antarctic circumpolar current during the late Eocene and early Oligocene (41 to 28 million yr ago) and the cooling of the Antarctic continent led to the ongoing oceanographic isolation of the Antarctic shelf (Scher \& Martin 2006). This cooling is thought to have reduced diversity in groups such as the bivalve molluscs, decapod crustaceans and teleost fish whilst encouraging adaptive radiation and endemism in the notothenoid fish and serolid crustaceans (Clarke 1992, Wilson et al. 2007). In molluscs, the well-established inverse relationship between latitude and species diversity may well be the result of major centers of radiation being located in the tropics (especially the Indo-West Pacific), with many species simply not yet reaching Antarctica (Crame 2000). The Antarctic shelf environment is of particular interest as recent geological studies have suggested that it may still be recovering from a relatively recent extinction event associated with the massive expansion of the Antarctic ice sheet during the last glacial maximum some 24 to 12 thousand yr ago (e.g. Thatje et al. 2005). We suggest that the twin effects of oceanographic isolation from larval input from lower latitudes and recent expansion and contraction of the Antarctic ice sheet have reduced the diversity of some Antarctic groups (e.g. molluscs) but allowed recent adaptive radiation in others, such as polychaetes. Future taxonomic revisions of the Antarctic polychaetes, incorporating molecular data alongside broad meta-analyses of species records, is necessary to test this hypothesis.

Acknowledgements. We acknowledge the outstanding support at sea of the many participants in the FOODBANCS project, the personnel from Raytheon Polar Services and the Masters and crew of the NSF Antarctic research vessels 'Laurence M. Gould' and 'Nathaniel B. Palmer'. A. Thurber assisted with sorting megacore samples in the laboratory. We are grateful to B. Ebbe and H. Feder for the loan of published raw data sets. The FOODBANCS Project was supported by grants from the National Science Foundation, Office of Polar Programs, to C.R.S. and D. J. DeMaster; this study was also supported by a grant from the Royal Society (UK). This is contribution 8134 from SOEST, University of Hawaii at Manoa.

\section{LITERATURE CITED}

Blake JA (1996) Family Paraonidae Cerruti, 1909. In: Blake JA, Hilbig B, Scott PH (eds) Taxonomic atlas of the benthic fauna of the Santa Maria Basin and the Western Santa Barbara Channel, Vol 6. Santa Barbara Museum of Natural History, Santa Barbara, CA, p 27-70

Brandt A, Gooday AJ, Brandao SN, Brix S and others (2007) First insights into the biodiversity and biogeography of the Southern Ocean deep sea. Nature 447:307-311

> Brey T, Klages M, Dahn M, Gorny C and others (1994) Antarctic benthic diversity. Nature 368:297 
Brose U, Martinez ND, Williams RJ (2003) Estimating species richness: sensitivity to sample coverage and insensitvity to spatial patterns. Ecology 84:2364-2377

Clarke A (1992) Is there a latitudinal diversity gradient in the sea? Trends Ecol Evol 7:286-287

Clarke KR, Gorley RN (2006) Primer v6: user manual. PrimerE, Plymouth

Clarke A, Johnston NM (2003) Antarctic marine benthic diversity. Oceanogr Mar Biol Annu Rev 41:47-114

Colwell RK, Coddington JR (1994) Estimating terrestrial biodiversity through extrapolation. Philos Trans R Soc Lond B 345:101-118

> Connell JH (1978) Diversity in tropical rain forests and coral reefs. Science 199:1302-1309

Cosson-Sarradin N, Sibuet M, Paterson GLJ, Vanriesheim A (1998) Polychaete diversity at tropical Atlantic deep-sea sites: environmental effects. Mar Ecol Prog Ser 165: 173-185

Crame JA (2000) Evolution of taxonomic diversity gradients in the marine realm: evidence from the composition of recent bivalve faunas. Paleobiology 26:188-214

Dayton PK (1990) Polar benthos. In: Polar oceanography, Part B: chemistry, biology and geology. Academic Press, London, p 631-686

Dell RK (1965) Marine biology. In: Hatherton T (ed) Antarctica: a New Zealand Antarctic Society Survey. Methuen \& Co, London, p 129-152

> Ducklow HW, Fraser W, Karl DM, Quetin LB and others (2006) Water-column processes in the West Antarctic Peninsula and the Ross Sea: interannual variations and foodweb structure. Deep-Sea Res II 53:834-852

Eicken H (1992) The role of sea ice in structuring Antarctic ecosystems. Polar Biol 12:3-13

Feder HM, Jewett SC, Blanchard AL (2007) Southeastern Chukchi Sea (Alaska) macrobenthos. Polar Biol 30: 261-275

Gage JD, Bett BJ (2005) Deep-sea benthic sampling. In: Holmes NA, McIntyre AD (eds) Methods for the study of the marine benthos. Blackwell Scientific Publications, Oxford, p 273-325

> Gage JD, May RM (1993) A dip into the deep sea. Nature 365:609-610

Gage JD, Tyler PA (1991) Deep sea biology. Cambridge University Press, Cambridge

Gallardo VA, Castillo JG, Retamal MA, Yáñez A (1977) Quantitative studies on the soft-bottom macrobenthic animal communities of shallow Antarctic bays. In: Llano GA (ed) Adaptations within antarctic ecosystems: Proceedings of the Third SCAR Symposium on Antarctic Biology. Smithsonian Institution, Washington, DC, p 361-387

Gambi MC, Castelli A, Guizzardi M (1997) Polychaete populations of the shallow soft bottoms off Terra Nova Bay (Ross Sea, Antarctica): distribution, diversity and biomass. Polar Biol 17:199-210

> Gaston KJ (2000) Global patterns in biodiversity. Nature 405: 220-227

> Glover A, Paterson G, Bett B, Gage J, Sibuet M, Sheader M, Hawkins L (2001) Patterns in polychaete abundance and diversity from the Madeira Abyssal Plain, northeast Atlantic. Deep-Sea Res Part I 48:217-236

> Glover AG, Smith CR, Paterson GLJ, Wilson GDF, Hawkins L, Sheader M (2002) Polychaete species diversity in the central Pacific abyss: local and regional patterns, and relationships with productivity. Mar Ecol Prog Ser 240: $157-170$

Glover AG, Smith CR, Mincks SL, Sumida PYG, Thurber A (2008) Macrofaunal abundance and composition on the
West Antarctic Peninsula continental shelf: evidence for a sediment 'food bank' and similarities to deep-sea habitats. Deep-Sea Res Part II 55:2491-2501

Gotelli NJ, Entsminger GL (2000) EcoSim: Null models software for ecology. Version 5.0. Acquired Intelligence Inc. \& Kesey-Bear. http://homepages.together.net/ gentsmin/ ecosim.htm.

Graf G (1992) Benthic-pelagic coupling: a benthic view. Oceanogr Mar Biol Annu Rev 31:149-190

Grassle JF, Maciolek NJ (1992) Deep-sea species richness: regional and local diversity estimate from quantitative bottom samples. Am Nat 139:313-341

Gray JS (2000) The measurement of marine species diversity, with an application to the benthic fauna of the Norwegian continental shelf. J Exp Mar Biol Ecol 250:23-49

- Gray JS (2001) Antarctic marine benthic biodiversity in a world-wide latitudinal context. Polar Biol 24:633-641

> Gray JS (2002) Species richness of marine soft sediments. Mar Ecol Prog Ser 244:285-297

> Gray JS, Poore GCB, Ugland KI, Wilson RS, Olsgard F, Johannessen $\varnothing ~(1997)$ Coastal and deep-sea benthic diversities compared. Mar Ecol Prog Ser 159:97-103

> Gutt J, Sirenko BI, Smirnov IS, Arntz WE (2004) How many macrozoobenthic species may inhabit the Antarctic shelf? Antarct Sci 16:11-16

Hessler RR, Sanders HL (1967) Faunal diversity in the deepsea. Deep-Sea Res 14:65-78

Hilbig B (2001) Deep-sea polychaetes in the Weddell Sea and Drake Passage: first quantitative results. Polar Biol 24: $538-544$

- Hilbig B (2004) Polychaetes of the deep Weddell and Scotia Seas: composition and zoogeographical links. Deep-Sea Res II 51:1817-1825

Hilbig B, Gerdes D, Montiel A (2006) Distribution patterns and biodiversity in polychaete communities of the Weddell Sea and Antarctic Peninsula area (Southern Ocean). J Mar Biol Assoc UK 86:711-725

Huston M (1979) A general hypothesis of species diversity. Am Nat 113:81-101

Jongman RHG, ter Braak CJF, Van Tongeren OFR (1987) Data analysis in community and landscape ecology. Cambridge University Press, Cambridge

Kukert H, Smith CR (1992) Disturbance, colonization and succession in a deep-sea sediment community: artificialmound experiments. Deep-Sea Res I 39:1349-1371

Leibold MA, Holyoak M, Mouquet N, Amarasekare P and others (2004) The metacommunity concept: a framework for multi-scale community ecology. Ecol Lett 7:601-613

Levin LA, Etter RJ, Rex MA, Gooday AJ and others (2001) Environmental influences on regional deep-sea species diversity. Annu Rev Ecol Syst 32:51-93

Magurran AE (2004) Measuring biological diversity. Blackwell Publishing, Oxford

> Mayer LM, Schick LL, Sawyer T, Plante CJ, Jumars PA, Self RFL (1995) Bioavailable amino acids in sediments: a biomimetic, kinetics-based approach. Limnol Oceanogr 40: 511-520

Mincks SL, Smith CR (2007) Recruitment patterns in Antarctic Peninsula shelf sediments: evidence of decoupling from seasonal phytodetritus pulses. Polar Biol 30:587-600

> Mincks SL, Smith CR, DeMaster DJ (2005) Persistence of labile organic matter and microbial biomass in Antarctic shelf sediments: evidence of a sediment 'food bank'. Mar Ecol Prog Ser 300:3-19

Mincks SL, Dyal PL, Paterson GLJ, Smith CR, Glover GA (2009) A new species of Aurospio (Polychaeta, Spionidae) from the Antarctic shelf, with analysis of its ecology, 
reproductive biology and evolutionary history. PSZNI: Mar Ecol 30:181-197

O'Hara RB (2005) Species richness estimators: How many species can dance on the head of a pin? J Anim Ecol 74: 375-386

Page TJ, Linse K (2002) More evidence of speciation and dispersal across the Antarctic Polar Front through molecular systematics of Southern Ocean Limatula (Bivalvia: Limidae). Polar Biol 25:818-826

Pianka ER (1966) Latitudinal gradients in species diversity: a review of concepts. Am Nat 100:33-46

Piepenburg D (2005) Recent research on Arctic benthos: common notions need to be revised. Polar Biol 28:733-755

Preston E, Preston JL (1975) Ecological structure in a West Indian gorgonian fauna. Bull Mar Sci 25:248-258

Raguá-Gil JM, Gutt J, Clarke A, Arntz WE (2004) Antarctic shallow-water mega-epibenthos: shaped by circumpolar dispersion or local conditions. Mar Biol 144:829-839

Rex MA, Etter RJ, Stuart CT (1997) Large-scale patterns of species diversity in the deep-sea benthos. In: Ormond RFG, Gage JD, Angel MV (eds) Marine biodiversity: patterns and processes. Cambridge University Press, Cambridge, p 94-117

Rex MA, Stuart CT, Hessler RR, Allen JA, Sanders HL, Wilson GDF (1993) Global-scale patterns of species diversity in deep-sea benthos. Nature 365:636-639

Rex MA, McClain CR, Johnson NA, Etter RJ, Allen JA, Bouchet P, Waren A (2005) A source-sink hypothesis for abyssal biodiversity. Am Nat 165:163-178

Richardson MD, Hedgpeth JW (1977) Antarctic soft-bottom, macrobenthic community adaptations to a cold, stable, highly productive, glacially affected environment. In: Llano GA (ed) Adaptations within Antarctic ecosystems: Proceedings of the Third SCAR Symposium on Antarctic Biology. Smithsonian Institution, Washington, DC, p 181-196

Rohde K (1992) Latitudinal gradients in species diversity: the search for the primary cause. Oikos 65:514-527

Rosenzweig ML (1995) Species diversity in space and time. Cambridge University Press, Cambridge

Sanders HL (1968) Marine benthic diversity: a comparative study. Am Nat 102:243-282

Schaff T, Levin L, Blair N, DeMaster D, Pope R, Boheme S (1992) Spatial heterogeneity of benthos on the Carolina continental slope: large (100 km)-scale variation. Mar Ecol Prog Ser 88:143-160

Scher HD, Martin EE (2006) Timing and climatic consequences of the opening of Drake Passage. Science 312: $428-430$

Shirayama Y, Fukushima T (1995) Comparisons of deep-sea sediments and overlying water collected using multiple corer and box corer. J Oceanogr 51:75-82

Schüller M, Ebbe B (2007) Global distributional patterns of selected deep-sea Polychaeta (Annelida) from the Southern Ocean. Deep-Sea Res II 54:1737-1751

Schüller M, Ebbe B, Wagele JW (2009) Community structure and diversity of polychaetes (Annelida) in the deep

Editorial responsibility: James McClintock,

Birmingham, Alabama, USA
Weddell Sea (Southern Ocean) and adjacent basins. Mar Biodivers 39:95-108

Sicinski J, Janowska E (1993) Polychaetes of the shallow sublittoral of Admirality Bay, King George Island, South Shetland Islands. Antarct Sci 5:161-167

Smith CR, Berelson W, Demaster DJ, Dobbs FC and others (1997) Latitudinal variations in benthic processes in the abyssal equatorial Pacific: control by biogenic particle flux. Deep-Sea Res II 44:2295-2317

Smith CR, Mincks S, DeMaster DJ (2006) A synthesis of bentho-pelagic coupling on the Antarctic shelf: food banks, ecosystem inertia and global climate change. Deep-Sea Res II 53:875-894

Smith CR, Mincks S, DeMaster DJ (2008) The FOODBANCS project: Introduction and sinking fluxes of organic carbon, chlorophyll $a$ and phytodetritus on the western Antarctic Peninsula continental shelf. Deep-Sea Res II 55: 2404-2414

Snelgrove PVR, Smith CR (2002) A riot of species in an environmental calm: the paradox of the species-rich deep-sea floor. Oceanogr Mar Biol Annu Rev 40:311-342

Sumida PYG, Bernardino AF, Stedall VP, Glover AG, Smith CR (2008) Temporal changes in benthic megafaunal abundance and composition across the West Antarctic Peninsula shelf: Results from video surveys. Deep-Sea Res II 55:2465-2477

ter Braak CJF, Smilauer P (2002) CANOCO reference manual and CanoDraw for Windows user guide: software for canonical community ordination (version 4.5). Microcomputer Power, New York, NY

Thatje S, Hillenbrand CD, Larter R (2005) On the origin of Antarctic marine benthic community structure. Trends Ecol Evol 20:534-540

Vernet M, Martinson D, Iannuzzi R, Stammerjohn S and others (2008) Primary production within the sea-ice zone west of the Antarctic Peninsula. Deep-Sea Res II 55: 2068-2085

> Walther BA, Moore JL (2005) The concepts of bias, precision, accuracy, and their use in testing the performance of species richness estimators, with a literature review of estimator performance. Ecography 28:815-829

Wilson GDF (1998) Historical influences on deep-sea isopod diversity in the Atlantic Ocean. Deep Sea Res II 45: 279-301

- Wilson GDF, Hessler RR (1987) Speciation in the deep sea. Annu Rev Ecol Syst 18:185-207

Wilson NG, Hunter RL, Lockhart SJ, Halanych KM (2007) Multiple lineages and absence of panmixia in the 'circumpolar' crinoid Promachocrinus kerguelensis from the Atlantic sector of Antarctica. Mar Biol 152:895-904

Witman JD, Etter RJ, Smith F (2004) The relationship between regional and local species diversity in marine benthic communities: a global perspective. Proc Natl Acad Sci USA 101:15664-15669

Wlodarska-Kowalczuk M, Sicinski J, Gromisz S, Kendall MA, Dahle S (2007) Similar soft-bottom polychaete diversity in Arctic and Antarctic marine inlets. Mar Biol 151:607-616

Submitted: August 5, 2010; Accepted: December 22, 2010

Proofs received from author(s): April 18, 2011 